\title{
Divalproex Sodium Attenuates Growth Hormone Response to Baclofen in Healthy Human Males
}

I-Shin Shiah, M.D., Lakshmi N. Yatham, M.B.B.S., F.R.C.P.C., Raymond W. Lam, M.D., F.R.C.P.C., and Athanasios P. Zis, M.D., F.R.C.P.C.

The effect of divalproex sodium (DVP) on $\gamma$-aminobutyric acid-B $\left(G A B A_{B}\right)$ receptor function in humans was assessed by measuring growth hormone (GH) responses to a challenge with a $G A B A_{B}$ receptor agonist, baclofen, in 10 male healthy volunteers. Each subject received $20 \mathrm{mg}$ of baclofen at 10:00 A.M., and blood samples were collected for measuring GH before and 30, 60, 90, 120, 150, $180 \mathrm{~min}$ after baclofen administration. The baclofen challenge test was repeated after 1 week of treatment with DVP $(1000 \mathrm{mg} /$ day). The results showed that the plasma GH response to baclofen was significantly attenuated by the DVP treatment and that the degree of attenuation was positively correlated with the blood levels of valproic acid. Our findings suggest that DVP downregulates hypothalamic $G A B A_{B}$ receptor function in humans. [Neuropsychopharmacology 18:370-376, 1998] (C) 1998 American College of Neuropsychopharmacology. Published by Elsevier Science Inc.
KEY WORDS: Divalproex sodium; GABA; GABA receptor; Baclofen; Growth hormone

Divalproex sodium (DVP) is an anticonvulsant that contains valproic acid and sodium valproate in a oneto-one molar ratio. This medication has recently been shown to be effective in treatment of acute mania (Bowden et al. 1994) and depression (Davis et al. 1996a), suggesting that, like lithium, it has antimanic and antidepressant properties. Although the mechanisms underlying the therapeutic effect of DVP in mood disorders have not been elucidated, the increase in $\gamma$-aminobutyric acid (GABA) levels in brain is the most often cited mechanism of action for the anticonvulsant activity of DVP (for a review, see Maes and Calabrese 1994).

From the Division of Mood Disorders, Department of Psychiatry, University of British Columbia, Vancouver, British Columbia, Canada.

Address correspondence to: Lakshmi N. Yatham, Assistant Professor in Psychiatry, Director, Mood Disorders Clinical Research Unit, Department of Psychiatry, University of British Columbia, 2255 Wesbrook Mall, Vancouver, B.C. V6T 2A1, Canada.

Received May 29, 1997; accepted August 29, 1997.
GABA is the main inhibitory neurotransmitter in the mammalian brain, and GABAergic transmission modulates a variety of other neurotransmitter and neuropeptide systems (Lloyd et al. 1989; Miller and Ferrendelli 1990). This neurotransmitter acts on two main receptors in the brain, $\mathrm{GABA}_{A}$ and $\mathrm{GABA}_{B}$ (Hill and Bowery 1981; Matsumoto 1989). In the past decade, some evidence has accumulated, implicating a role for $\mathrm{GABA}_{\mathrm{B}}$ receptors in the pathophysiology of mood disorders and in the mechanism of action of antidepressants and mood stabilizers. In animal studies, for instance, a decrease in cortical $\mathrm{GABA}_{\mathrm{B}}$ binding has been shown in the animal models of depression such as the helpless rats and the olfactory bulbectomized rats (Lloyd and Morselli 1987). Chronic administration of tricyclic antidepressants (TCAs) normalizes cortical $\mathrm{GABA}_{B}$ receptor density in both helpless (Martin et al. 1989) and bulbectomized (Joly et al. 1987) rats. Furthermore, chronic administration of antidepressants, including TCAs, monoamine oxidase inhibitors (MAO-Is), selective serotonin reuptake inhibitors (SSRIs), atypical antidepressants, mood stabilizers such as lithium, carbamazepine, 
valproate, and electroconvulsive shock (ECS), has been reported to increase $\mathrm{GABA}_{\mathrm{B}}$ receptors in rat cortex or hippocampus (Lloyd et al. 1985; Lloyd and Pichat 1987; Szekely et al. 1987; Motohashi et al. 1989; Motohashi 1992; Pratt and Bowery 1993). Several other studies, however, were unable to confirm upregulation of $\mathrm{GABA}_{\mathrm{B}}$ receptors in the rat frontal cortex after antidepressant treatments (Cross and Horton 1987, 1988; McManus and Greenshaw 1991; Engelbrecht et al. 1994).

In humans, one way to assess $\mathrm{GABA}_{\mathrm{B}}$ receptor function is to measure growth hormone $(\mathrm{GH})$ release after administration of baclofen, a $\beta$-p-chlorophenyl derivative of GABA and a $\mathrm{GABA}_{B}$ receptor agonist (Muller 1987). This endocrine challenge paradigm is based on two observations: (1) that hypothalamic $\mathrm{GABA}_{\mathrm{B}}$ receptor sites are involved in the modulation of $\mathrm{GH}$ secretion (Gamse et al. 1980; Muller 1987), and (2) that the administration of baclofen induces a significant increase in GH concentrations in normal healthy humans (Koulu et al. 1979). Using this paradigm, two out of three studies (Marchesi et al. 1991; O'Flynn and Dinan 1993; Monteleone et al. 1990a) demonstrated a significant reduction of $\mathrm{GH}$ response to baclofen in patients with major depression compared with matched healthy controls, supporting the idea that downregulated $\mathrm{GABA}_{\mathrm{B}}$ receptor function is associated with depression. To our knowledge, there is no study to date that examined the $\mathrm{GABA}_{\mathrm{B}}$ receptor function in manic patients. Similarly, no studies to date examine the effect of DVP on $\mathrm{GABA}_{\mathrm{B}}$ receptors in humans. The purpose of this study, therefore, was to examine the effect of DVP on the $\mathrm{GABA}_{\mathrm{B}}$ receptor function in humans by measuring GH release to baclofen challenge in 10 male healthy volunteers before and after 1 week of DVP treatment.

\section{METHODS}

\section{Subjects}

Ten male healthy volunteers (mean age \pm SD: $25.9 \pm$ 5.8 years) gave written informed consent for participation in the study, which had been approved by the Clinical Research Ethics Committee of the University of British Columbia. Subjects were evaluated with the Structured Clinical Interview for DSM-III-R non-patient version (SCID-NP; Spitzer et al. 1992), a medical history and a physical examination by a research psychiatrist. All subjects had no past or present psychiatric history and had no current medical conditions. They were free of a family history of psychiatric illness in first-degree relatives. They were also medication-free for a minimum of 4 weeks prior to study, smoked fewer than five cigarettes per day, and ingested no more than the equivalent of five beers per week and three cups of coffee per day.

\section{Procedures}

Subjects, having fasted from midnight, reported to the research unit between 8:00 A.M. and 8:30 A.M. on the day of the baclofen test. After being weighed (mean weight \pm SD: $79.0 \pm 14.5 \mathrm{~kg}$ ), they reclined on a bed in a comfortable position with the head elevated. An intravenous cannula was inserted in a forearm vein at 8:30 A.M., and subjects were allowed to rest but not to sleep, smoke, or eat. The first blood sample for baseline GH level was taken at 10:00 A.M. (time "0"). Baclofen $20 \mathrm{mg}$ was given orally at this time, and further blood samples were collected every $30 \mathrm{~min}$ for $3 \mathrm{~h}$ (six samples). Subjects also rated at baseline, $60,120,180 \mathrm{~min}$ on $100 \mathrm{~mm}$ visual analogue scales (VAS; $0=$ not at all, $100=$ most ever) on four subjective states (nausea, drowsiness, headache, concentration). Pulse rate and blood pressure were recorded at regular intervals throughout the procedure.

After the pretreatment study, subjects received DVP $1,000 \mathrm{mg} /$ day $(500 \mathrm{mg}$ in the morning and $500 \mathrm{mg}$ in the evening) for 7 consecutive days on an outpatient basis. During the 7 days, subjects were asked to record the side effects of DVP with an open questionnaire. The side effects reported in the questionnaire were classified as mild, moderate, and severe, and were defined by "not affecting usual activity," "mild disruption in usual activity," and "major disruption in usual activity," respectively. Subjects took the last dose of DVP at 10:00 P.M. on the 7th day, and baclofen challenge was repeated at 8:30 A.M. of the 8th day. An additional blood sample was taken at 10:00 A.M. (12 $\mathrm{h}$ after the final dose) on the day of testing for measuring the blood levels of valproic acid to check for compliance (mean valproic acid level \pm SD: $513.8 \pm 92.4 \mu \mathrm{mol} / \mathrm{L}$ ). Dose and drug administration as well as hormonal and behavioral monitoring were identical to those in the pretreatment study.

\section{Biochemical Assays}

Venous samples were collected into tubes containing EDTA, stored on ice, and centrifuged within $60 \mathrm{~min}$. Serum was separated and then was stored at $-80^{\circ} \mathrm{C}$ for assay at a later time. All samples from each subject were assayed in the same batch. The samples were assayed by a lab technician blind to the study conditions. Valproic acid concentrations were determined using Fluorescence Polarization Immunoassay (FPIA), GH was assayed by Quantitope HGH Radioimmunoassay (Kallestad diagnostics). The sensitivity of GH assay was 0.2 $\mathrm{ng} / \mathrm{ml}$. The interassay coefficients of variation were $10.8 \%$ for GH pool of $2.6 \mathrm{ng} / \mathrm{ml}, 6.6 \%$ for $\mathrm{GH}$ pool of 5.8 $\mathrm{ng} / \mathrm{ml}$, and $5.7 \%$ for $\mathrm{GH}$ pool of $11.3 \mathrm{ng} / \mathrm{ml}$. The intraassay coefficients for $\mathrm{GH}$ were $6.8 \%, 5 \%$, and $9.1 \%$ for $\mathrm{GH}$ pools of $2.5 \mathrm{ng} / \mathrm{ml}, 5.4 \mathrm{ng} / \mathrm{ml}$, and $35.2 \mathrm{ng} / \mathrm{ml}$, respectively. 


\section{Statistics}

Wilcoxon signed-rank test was used to compare the baseline GH levels between pre- and posttreatment conditions, because the GH data were not normally distributed. Repeated measures analysis of variance (ANOVA) was used to examine the treatment effect of DVP on the $\mathrm{GH}$ responses to baclofen, which were measured as the net change from baseline at each time point after challenge (labeled as $\Delta \mathrm{GH}$ ). Post hoc comparisons were carried out using Wilcoxon signed-rank tests. The GH responses were also calculated as (1) the net maximal response (labeled as $\Delta_{\max } \mathrm{GH}$ ), that is, the peak response minus baseline, and (2) the net area under the time curve (labeled as AUC GH), using trapezoidal method with subtraction of the baseline values. The change in $\Delta_{\max }$ GH was defined by the difference between pretreatment $\Delta_{\max } \mathrm{GH}$ and posttreatment $\Delta_{\max }$ GH. Behavioral responses to baclofen (labeled as $\Delta_{\max }$ VAS scores) were calculated as the difference between baseline VAS scores and maximal peak scores. The $\Delta_{\max }$ and AUC GH data as well as $\Delta_{\max }$ VAS scores were analyzed with Wilcoxon signed-rank tests. Relationships between variables were assessed by means of Spearman's rank order correlation coefficients. All significance levels reported were two-tailed. Data were reported as mean $\pm \mathrm{SD}$. The data were analyzed using the Statistical Package for Social Sciences (SPSS) software.

\section{RESULTS}

The data for baseline, peak, $\Delta_{\max }$ and AUC GH of the 10 subjects are presented in Table 1 . Two out of the 10 sub- jects were excluded from data analysis. One subject did not have an increase in GH response to baclofen challenge before DVP treatment (defined by $\Delta_{\max } \mathrm{GH}>0.5$ $\mathrm{ng} / \mathrm{ml}$, Davis et al. 1996b), and the other one had baseline GH levels above $5 \mu \mathrm{g} / \mathrm{L}$ post-treatment. The exclusion of subjects with large baseline GH levels is standard practice because after a GH secretory episode, the pituitary is relatively refractory (Vance et al. 1985). For the remaining eight subjects, there was no significant difference in baseline plasma GH levels between pretreatment and posttreatment conditions $(0.56 \pm 0.32 \mathrm{vs}$. $0.98 \pm 0.70 \mathrm{ng} / \mathrm{ml} ; \mathrm{Z}=-1.54, p=.12)$. The baclofeninduced GH response measured as $\Delta_{\max } \mathrm{GH}$ was significantly attenuated after DVP treatment (pre- vs. posttreatment, $4.34 \pm 3.30$ vs. $2.78 \pm 3.15 \mathrm{ng} / \mathrm{ml}, \mathrm{Z}=-1.96$, $p=.05)$. There was also a significant reduction in the AUC GH after DVP treatment compared with pretreatment (pre- vs. posttreatment, $320.3 \pm 219.8$ vs. $129.7 \pm$ $207.2 \mathrm{ng} \times \mathrm{min} / \mathrm{ml} ; \mathrm{Z}=-2.52, p<.02)$.

$\Delta \mathrm{GH}$ levels at various time points for the eight subjects are plotted in Figure 1. Repeated measures ANOVA on the $\Delta \mathrm{GH}$ data showed a significant time effect $(\mathrm{F}=3.722, d f=6,42, p<.006)$, a significant treatment effect $(\mathrm{F}=21.667, d f=1,7, p<.002)$, but no significant interaction between time and treatment $(\mathrm{F}=1.38$, $d f=6,42, p=.24)$. Post hoc analyses using Wilcoxon signed-rank test showed a significantly attenuated GH response at $90 \mathrm{~min}$ after DVP treatment compared with pretreatment (pre- vs. posttreatment, $3.84 \pm 3.59$ vs. $1.09 \pm 1.61 \mathrm{ng} / \mathrm{ml}, \mathrm{Z}=-2.36, p<.02)$.

As shown in Figure 2, there was a significant positive correlation between the changes in $\Delta_{\max } \mathrm{GH}$ response (that is, the pretreatment $\Delta_{\max } \mathrm{GH}$ minus posttreatment $\Delta_{\max } \mathrm{GH}$ ) and the blood levels of valproic acid (Spearman's $r=0.786, p<.03)$, suggesting that the higher the

Table 1. Growth Hormone Responses to Baclofen in Healthy Males before and after Treatment with Divalproex

\begin{tabular}{|c|c|c|c|c|c|c|c|c|}
\hline \multirow[b]{2}{*}{ Subject } & \multicolumn{4}{|c|}{ Pre-Divalproex } & \multicolumn{4}{|c|}{ Post-Divalproex } \\
\hline & Baseline GH & Peak GH & $\Delta_{\max } \mathrm{GH}$ & AUC GH & Baseline GH & Peak GH & $\Delta_{\max } \mathbf{G H}$ & AUC GH \\
\hline 1 & 0.94 & 3.44 & 2.50 & 211.1 & 0.67 & 1.44 & 0.77 & 46.9 \\
\hline 2 & 0.08 & 2.11 & 2.03 & 185.3 & 0.98 & 1.42 & 0.44 & -4.9 \\
\hline 3 & 0.67 & 9.76 & 9.09 & 739.5 & 0.37 & 9.44 & 9.07 & 622.8 \\
\hline 4 & 0.82 & 2.51 & 1.69 & 160.3 & 1.17 & 1.60 & 0.43 & -22.8 \\
\hline 5 & 0.33 & 4.61 & 4.28 & 317.4 & 0.90 & 6.40 & 5.50 & 133.3 \\
\hline 6 & 0.17 & 1.03 & 0.86 & 57.7 & 0.40 & 0.80 & 0.40 & 39 \\
\hline 7 & 0.80 & 5.70 & 4.90 & 388.6 & 2.60 & 6.40 & 3.80 & 97.9 \\
\hline 8 & 0.70 & 10.10 & 9.40 & 502.8 & 0.80 & 2.70 & 1.90 & 125.8 \\
\hline Mean \pm SD & $0.56 \pm 0.32-a$ & $4.90 \pm 3.42$ & $4.34 \pm 3.30-b$ & $320.3 \pm 219.8-c$ & $0.98 \pm 0.70-d$ & $3.77 \pm 3.19$ & $2.78 \pm 3.15$ & $129.7 \pm 207.2-f$ \\
\hline 9 & 1.39 & 1.34 & -0.05 & -83.55 & 1.04 & 3.90 & 2.86 & 136.6 \\
\hline 10 & 1.05 & 4.55 & 3.50 & 164.2 & 6.72 & 5.69 & -1.03 & -504.3 \\
\hline
\end{tabular}

$\mathrm{GH}=$ growth hormone $(\mathrm{ng} / \mathrm{ml}) ; \Delta_{\max } \mathrm{GH}(\mathrm{ng} / \mathrm{ml})=$ peak minus baseline GH levels;

$\operatorname{AUC~GH}(\mathrm{ng} \times \mathrm{min} / \mathrm{ml})=$ growth hormone response to baclofen calculated as net area under curve $\left(\mathrm{AUC}_{0-180}\right)$.

$a$ vs. $d: p=.12, b$ vs. $e: p=.05, c$ vs. $f: p<.02$ (Wilcoxon signed-rank tests).

Subject 9 had the highest baseline GH pretreatment $(1.39 \mathrm{ng} / \mathrm{ml})$ and did not have an increase GH response (defined by $\left.\Delta_{\max } \mathrm{GH}>0.5 \mathrm{ng} / \mathrm{ml}\right)$.

Subject 10 had a baseline $\mathrm{GH}$ level above $5 \mathrm{ng} / \mathrm{ml}$ posttreatment $(6.72 \mathrm{ng} / \mathrm{ml})$. 


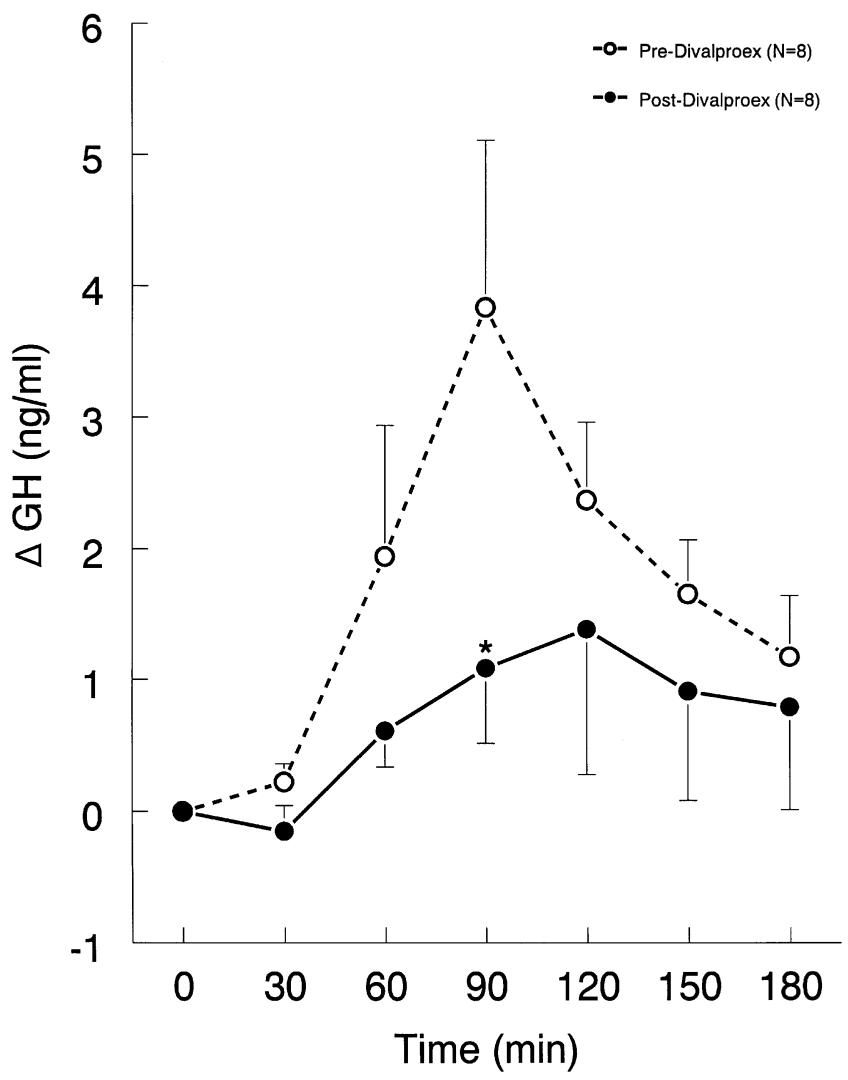

Figure 1. Mean ( \pm SEM) GH responses to baclofen in eight healthy males before and after 1 week of DVP treatment. The baclofen-induced GH release was significantly attenuated after DVP treatment compared with those responses pretreatment (repeated measures of ANOVA on $\Delta \mathrm{GH}$ data; Post hoc Wilcoxon signed-rank tests, $\left.{ }^{*} p<.05\right)$.

blood levels of valproic acid, the more attenuated the GH responses to baclofen. There was, however, no significant correlation between the changes in $\Delta_{\max } \mathrm{GH}$ response and age (Spearman's $r=0.268, p=.52$ ) or body weight (Spearman's $r=0.286, p=.69$ ).

With regard to behavioral responses, baclofen administration significantly decreased concentration $(\mathrm{Z}=$ $-1.96, p=.05)$ but overall did not have a significant effect on nausea $(Z=.00, p=1.0)$, headache $(Z=-0.38$, $p=.70)$ or drowsiness $(Z=-0.48, p=.62)$. DVP treatment did not significantly alter any of these behavioral responses. There were no correlations between $\Delta_{\max } \mathrm{GH}$ levels and $\Delta$ VAS scores of concentration, nausea, headache, or drowsiness either before or after DVP treatment (data not shown). The adverse events with DVP, which were reported with open questionnaires, included stomach upset and diarrhea $(12.5 \%$ with mild degree), headache (25\% with mild degree), feeling tired ( $25 \%$ with moderate degree), feeling sleepy $(12.5 \%$ with moderate degree), and feeling moody ( $12.5 \%$ with moderate degree). Three out of the eight subjects did not report any significant side effects.

\section{DISCUSSION}

Our major findings in the present study included: (1) administration of baclofen, a $\mathrm{GABA}_{\mathrm{B}}$ receptor agonist, significantly increased plasma GH levels in healthy male humans; (2) 1-week treatment with DVP significantly attenuated the GH response to baclofen; and (3) there was a significant positive correlation between the degree of attenuation of GH responses and the blood levels of valproic acid.

Our finding of an increase in GH release in healthy males after administration of $20 \mathrm{mg}$ of baclofen is consistent with previous studies (Monteleone et al. 1990a, 1990b; O'Flynn and Dinan 1993; Lucey et al. 1994; Davis et al. 1996b) and further supports a role for $\mathrm{GABA}_{\mathrm{B}}$ receptors in modulating $\mathrm{GH}$ release in humans. One of our study subjects, however, failed to significantly increase GH response to baclofen. This was also reported in two previous studies, which showed some healthy subjects did not have an increased GH response to 20 mg dose of baclofen (Lucey et al. 1994; Davis et al. 1996b). It is unclear why some normal subjects have little or no GH response to baclofen (Davis et al. 1996b). But, it is of interest to note that in our 10 study subjects, the only subject who did not have an increase in GH response, had the highest baseline GH pretreatment (1.39 $\mathrm{ng} / \mathrm{ml}$ ). Such a finding supports the view that subjects with high baseline GH levels may show blunted response to a subsequent pharmacological challenge (Laakmann et al. 1990; Davis et al. 1996b).

Our finding of an attenuation of $\mathrm{GABA}_{\mathrm{B}}$-mediated endocrine response to DVP in healthy males suggests that DVP downregulated hypothalamus $\mathrm{GABA}_{\mathrm{B}}$ receptors in the study subjects. Although the sample size for this study was relatively small, the attenuating effect of DVP was further confirmed by the positive correlation between the degree of attenuation measured as change in $\Delta_{\max } \mathrm{GH}$ and the blood levels of valproic acid. Because we did not include a placebo control condition to minimize the effects of confounding variables such as stress effects and variations in baseline hormone levels, we can not exclude the possibility of a Type I error of inference (Thompson et al. 1994). In addition, we did not measure the plasma levels of baclofen. We, therefore, can not exclude the possibility of a pharmacokinetic interaction between baclofen and DVP leading to lower plasma baclofen levels during posttreatment condition, and hence lower GH response. Such, however, seems unlikely as pharmacokinetic data have shown that DVP and baclofen are metabolized through different mechanisms. DVP is metabolized via glucuronidation or oxidation (McNamara 1996), whereas baclofen is excreted unaltered in the urine $(85 \%)$ or metabolized via deamination (Krogh 1995).

It is of interest to note that our finding is at variance with two rat studies, which demonstrated that chronic 


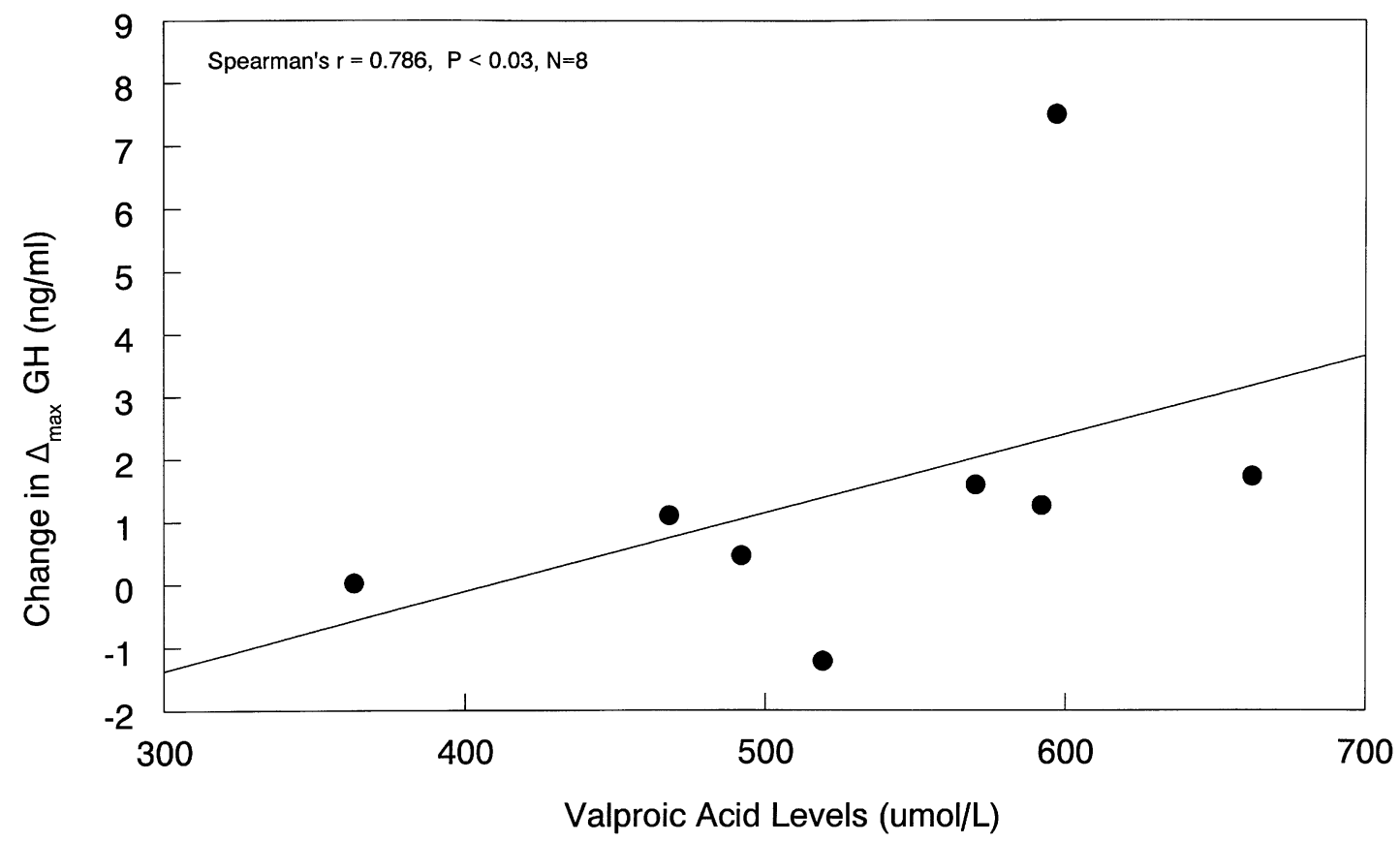

Figure 2. The degree of attenuation effect of DVP on baclofen-induced GH response, measured as change in $\Delta_{\max } \mathrm{GH}$, and the blood levels of valproic acid in eight healthy males. The line indicates a significant positive correlation between change in $\Delta_{\max } \mathrm{GH}$, and blood levels of valproic acid (Spearman's correlation, $p<.03$ ).

treatment with sodium valproate significantly increased $\mathrm{GABA}_{\mathrm{B}}$ receptors in the rat hippocampus or frontal cortex (Motohashi 1992; Lloyd et al. 1985). Because these two animal studies did not examine the effect of valproate on the hypothalamic $\mathrm{GABA}_{\mathrm{B}}$ receptors, and that there is, to date, no other study that examined the effect of DVP on $\mathrm{GABA}_{\mathrm{B}}$ receptors in different brain regions, we do not know if valproate treatment alters (up- or downregulates) the hypothalamic $\mathrm{GABA}_{\mathrm{B}}$ receptors in the rat. This raises the possibility that DVP may have differential effects on $G_{A B A}$ receptors in different brain regions. That is, DVP may upregulate $\mathrm{GABA}_{\mathrm{B}}$ receptors in the hippocampus or frontal cortex while downregulating those in the hypothalamus. In support of this hypothesis, some indirect evidence has been provided by regional brain studies of rats. Patsalos and Lascelles (1981) showed that that 10 days of treatment with sodium valproate significantly elevated the brain GABA concentrations in several brain regions including the hippocampus, cerebral cortex, pons and medulla, and cerebellum, but produced little change in GABA levels in the hypothalamus, striatum, and mid-brain. Baf et al. (1994) examined the treatment effect of sodium valproate on monoamine levels in different regions of the rat brain. They found that after 45 days of administration of sodium valproate, there was a significant increase in norepinephrine levels in hippocampus and brain stem, whereas a significant decrease was noted in hypothalamus. Serotonin levels were significantly increased in striatum-accumbens, brain stem, motor cortex, and hippocampus, but they were significantly decreased in hypothalamus and cerebellum. Furthermore, the only animal study that examined the effects of another mood stabilizer, lithium, on GABA receptor binding in hypothalamus, has shown a decrease in $\left[{ }^{3} \mathrm{H}\right]-\mathrm{GABA}$ binding sites in rat hypothalamus after chronic administration of lithium (Maggi and Enna 1980). This is in agreement with the result of our study, which showed a downregulation of hypothalamic $\mathrm{GABA}_{\mathrm{B}}$ receptor function with DVP treatment.

An alternative explanation for the discrepancy in findings between our study and the animal studies is species differences in $\mathrm{GABA}_{B}$ receptor responsivity to valproate between humans and rodents. Consistent with this hypothesis, studies that examined the effects of valproate on $5-\mathrm{HT}_{1 \mathrm{~A}}$ receptor responsivity, have demonstrated conflicting results between humans and rats. In humans, we have recently found that DVP significantly attenuates the hypothermic response to ipsapirone, a $5-\mathrm{HT}_{1 \mathrm{~A}}$ receptor agonist, in 10 healthy males (Shiah et al. 1997). In rats, however, Khaitan et al. (1994) reported that DVP did not alter the hypothermic response to 8-OH-DPAT (a prototypic $5-\mathrm{HT}_{1 \mathrm{~A}}$ receptor agonist). In addition, Monteleone et al. (1990b) reported that 28 days of amitriptyline $(100 \mathrm{mg} /$ day $)$ treatment did not significantly alter the GH response to baclofen in eight male depressed patients. A subsequent study by the same group (Monteleone et al. 1990a) reported that 15 and 35 days of treatment with amitriptyline (100 $\mathrm{mg} /$ day), imipramine (100 mg/day) and fluoxetine (20 
$\mathrm{mg}$ /day) also did not modify this endocrine response in 10 male depressed patients, even when a clear therapeutic effect was obtained. These findings are in contrast with those of rat studies that showed an upregulation of $\mathrm{GABA}_{\mathrm{B}}$ receptors after chronic administration of antidepressants (Lloyd et al. 1985; Lloyd and Pichat 1987).

Chronic treatment with DVP (Petty et al. 1996) and ECS (Devanand et al. 1995), but not desipramine (Petty et al. 1993), has been reported to reduce plasma GABA levels in patients with mood disorders. Furthermore, in manic patients treated with DVP (Petty et al. 1996) and in depressed patients receiving ECS (Devanand et al. 1995), higher plasma GABA levels predicted better treatment response. To interpret these data, Petty (1995) formulated a GABA hypothesis for mood disorders. He postulated that low GABA function may be a genetic trait marker of vulnerability for development of mood disorders. Environmental factors, including stress and excessive alcohol use, may increase GABA, causing symptoms of depression or mania. Somatic treatments such as DVP and ECS return GABA to its presymptomatic baseline as the symptoms remit. Given that low $\mathrm{GABA}_{\mathrm{B}}$ receptor function may be associated with depression (Marchesi et al. 1991; O'Flynn and Dinan 1993), our finding of attenuation of $\mathrm{GABA}_{\mathrm{B}}$-mediated $\mathrm{GH}$ response to DVP appears to support Petty's hypothesis. Further studies of the treatment effect of mood stabilizers and ECS on the GH response to baclofen in patients with depression and mania are needed to strengthen this hypothesis.

In summary, we found that DVP treatment significantly attenuated baclofen-induced GH response in humans, and this attenuating effect was related to blood levels of valproic acid. Our findings may suggest that downregulation of $\mathrm{GABA}_{B}$ receptor function in the hypothalamus is involved in the mechanism of action of DVP in humans. The results of this study should, however, be viewed as preliminary, in light of the small sample size and the lack of placebo control. Further studies are required to replicate our findings before any firm conclusion can be drawn.

\section{ACKNOWLEDGMENTS}

I-Shin Shiah, a clinical fellow, was funded by a grant from TriService General Hospital and National Defense Medical Center, Taipei, Taiwan. The authors thank Ann O'Brien and Azim Jamani for invaluable technical assistance. DVP was supplied by Abbott Pharmaceuticals.

\section{REFERENCES}

Baf MH, Subhash MN, Madepalli Lakshmana K, Sridhara Rama Rao BS (1994): Sodium valproate induced alter- ations in monoamine levels in different regions of the rat brain. Neurochem Int 24:67-72

Bowden CL, Brugger AM, Swann AC, Calabrese JR, Janicak PG, Petty F, Dilsaver SC, Davis JM, Rush AJ, Small JG, Garza-Trevino ES, Craig Risch S, Goonick PJ, Morris DD (1994): Efficacy of divalproex vs. lithium and placebo in the treatment of mania. JAMA 271:918-924

Cross JA, Horton RW (1987): Are increases in $\mathrm{GABA}_{\mathrm{B}}$ receptors consistent findings following chronic antidepressant administration? Eur J Pharmacol 141:159-162

Cross JA, Horton RW (1988): Effects of chronic oral administration of the antidepressants, desmethylimipramine and zimelidine on rat cortical $\mathrm{GABA}_{\mathrm{B}}$ binding sites: $\mathrm{A}$ comparison with $5-\mathrm{HT}_{2}$ binding site changes. Br J Pharmacol 93:331-336

Davis LL, Kabel D, Dhiren Patel DO, Choate AD, FoslienNash C, Gurguis GNM, Kramer GL, Petty F (1996a): Valproate as an antidepressant in major depressive disorder. Psychopharmacol Bull 32:647-652.

Davis LL, Trivedi M, Kramer GL, Rush AJ, Orsulak PJ, Akers L, Petty F (1996b): Growth hormone response to baclofen: A comparison of 10-mg and 20-mg doses in healthy men. Psychiatr Res 60:41-47

Devanand DP, Shapira B, Petty F, Fitzsimons L, Lerer B, Sackeim HA (1995): Effects of electroconvulsive therapy on plasma GABA. Convulsive Ther 11:3-13

Engelbrecht AH, Russell VA, Taljaard JJF (1994): Lack of effect of bilateral locus coeruleus lesion and antidepressant treatment of gamma-aminobutyric acid receptors in the rat frontal cortex. Neurochemical Res 9:1119-1123

Gamse R, Vaccaro DE, Gamse G, Dipace M, Fox TO, Leeman SE (1980): Release of immunoreactive somatostatin from hypothalamic cell culture: Inhibition by gamma-aminobutyric acid. Proc Natl Acad Sci USA 77:5552-5556

Goodwin FK, Jamison KR (1990): Manic Depressive Illness. New York, Oxford University Press, pp 417-425

Hill DR, Bowery NG (1981): $\left[{ }^{3} \mathrm{H}\right]$ Baclofen and $\left[{ }^{3} \mathrm{H}\right]$ GABA bind to bicuculline-insensitive GABA-B sites in rat brain. Nature 290:149-152

Joly D, Lloyd KG, Pichat P, Sanger DJ (1987): Correlation between the behavioral effect of desipramine and $\mathrm{GABA}_{B}$ receptor regulation in the olfactory bulbectomized rat. $\mathrm{Br}$ J Pharmacol 90:125P

Khaitan L, Calabrese JR, Stockmeier CA (1994): Effects of chronic treatment with valproate on serotonin-1A receptor binding and function. Psychopharmacology 113:539-542

Koulu M, Lammintausta R, Dahlstrom S (1979): Stimulatory effect of acute baclofen administration on human growth hormone and prolactin secretion in man. J Clin Endocrinol Metab 48:1038-1040

Krogh CME (1995): Compendium of Pharmaceuticals and Specialties, 30th ed. Canadian Pharmaceutical Association, Ottawa, pp 704-705

Laakmann G, Hinz A, Voderholzer U, Daffner C, Muller OA, Neuhauser H, Neulinger E (1990): The influence of psychotropic drugs and releasing hormones on anterior pituitary hormones secretion in healthy subjects and depressed patients. Pharmacopsychiatry 23:18-26

Lloyd KG, Thuret F, Pilc A (1985): Upregulation of $\gamma$-aminobutyric acid $(\mathrm{GABA})_{\mathrm{B}}$ binding sites in rat frontal cor- 
tex: A common action of repeated administration of different classes of antidepressants and electroshock. J Pharmacol Exp Ther 235:191-199

Lloyd KG, Morselli PL (1987): Psychopharmacology of GABAergic drugs. In Meltzer HG (ed), Psychopharmacology: The Third Generation of Progress. New York, Raven Press, pp 183-195

Lloyd KG, Pichat P (1987): GABA synapses, depression and antidepressant drugs. In Dahl SG, Gram SMP, Potter WZ (eds), Clinical Pharmacology in Psychiatry. Berlin, Springer-Verlag, pp 113-126

Lloyd KG, Zivkovic B, Scatton B, Morselli PL, Bartholini G (1989): The GABAergic hypothesis of depression. Prog Neuropsychopharmacol Biol Psychiatry 13:341-351

Lucey JV, Butcher G, O'Flynn K, Clare AW, Dinan G (1994): The growth hormone response to baclofen in obsessive compulsive disorder-does the GABA-B receptor mediate obsessive anxiety? Pharmacopsychiatry 27:23-26

Maes M, Calabrese JR (1994): Mechanisms of action of valproate in affective disorders. In Joffe RT, Calabrese JR (eds), Anticonvulsants in Mood Disorders. New York, Macel Dekker, Inc., pp 933-944

Maggi A, Enna SJ (1980): Regional alterations in rat brain neurotransmitter systems following chronic lithium treatment. J Neurochem 34:888-892

Marchesi C, Chiodera P, De Ferri A, De Risio C, Dasso L, Menozzi P, Volpi R, Coiro V (1991): Reduction of GH response to the GABA-B agonist baclofen in patients with major depression. Psychoneuroendocrinology 16:475-479

Martin P, Pichat P, Massol J, Sourbrie P, Lloyd KG, Puech AJ (1989): Decrease $\mathrm{GABA}_{B}$ receptors in helpless rats: Reversal by tricyclic antidepressants. Neuropsychobiology 22:220-224

Matsumoto RR (1989): GABA receptors: Are cellular differences reflected in function? Brain Res Rev 14:203-225

McManus DJ, Greenshaw AJ (1991): Differential effects of antidepressants on $\mathrm{GABA}_{\mathrm{B}}$ and $\beta$-adrenergic receptors in rat cerebral cortex. Biochem Pharmacol 42:1525

Miller JM, Ferrendelli JA (1990): Characterization of GABAergic seizure regulation in the midline thalamus. Neuropharmacology 29:649-655

McNamara J (1996): Drugs effective in the therapy of the epilepsies. In Hardman LG, Limbird LE (eds), Goodman \& Gilman's The Pharmacological Basis of Therapeutics, 9th ed. New York, McGraw-Hill Inc., pp 476-477

Monteleone P, Maj M, Iovino M, Steardo L (1990a): GABA, depression and the mechanism of action of antidepressant drugs: A neuroendocrine approach. J Affective Disord 20:1-5

Monteleone P, Steardo L, Tanzillo C, Maj M (1990b): Chronic antidepressant drug treatment does not affect $\mathrm{GH}$ response to baclofen in depressed subjects. J Neural Transm 82:147-152

Motohashi N, Ikawa K, Kariya T (1989): GABA B $_{\text {receptors }}$ are up-regulated by chronic treatment with lithium or carbamazepine. GABA hypothesis of affective disorders? Eur J Pharmacol 166:95-99

Motohashi N (1992): GABA receptor alterations after chronic lithium administration. Comparison with carbamazepine and sodium valproate. Prog Neuropsychopharmacol Biol Psychiatry 16:571-579

Muller EE (1987): Neural control of somatotropic function. Physiol Rev 67:962-1053

O'Flynn K, Dinan TG (1993): Baclofen-induced growth hormone release in major depression: Relationship to dexamethasone suppression test result. Am J Psychiatry 150:1728-1730

Patsalos PN, Lascelles PT (1981): Changes in regional brain levels of amino acid putative neurotransmitters after prolonged treatment with the anticonvulsant drugs diphenylhydantoin, phenobarbitone, sodium valproate, ethosuximide, and sulthiame in the rat. J Neurochem 36:688-695

Petty F, Steinberg J, Kramer GL, Fulton M, Moeller FG (1993): Desipramine does not alter plasma GABA in patients with major depression. J Affective Disord 29:53-56

Petty F (1995): GABA and mood disorders: A brief review and hypothesis. J Affective Disord 34:275-281

Petty F, Rush AJ, Davis JM, Calabrese JR, Kimmel SE, Kramer GL, Small JG, Miller MJ, Swann AE, Orsulak PJ, Blake ME, Bowden CL (1996): Plasma GABA predicts acute response to divalproex in mania. Biol Psychiatry 39:278-284

Pratt GD, Bowery NG (1993): Repeated administration of desipramine and a $\mathrm{GABA}_{\mathrm{B}}$ receptor antagonist, CGP 36742 , discretely up-regulates $\mathrm{GABA}_{\mathrm{B}}$ receptor binding sites in rat frontal cortex. Br J Pharmacol 110:724-735

Shiah IS, Yatham LN, Lam RW, Zis AP (1997): Effects of divalproex sodium on 5-HT1A receptor function in healthy human males: Hypothermic, hormonal, and behavioral responses to ipsapirone. Neuropsychopharmacology 17:382-390

Spitzer RL, Williams JBW, Gibbon M, First MB (1992): Structured Clinical Interview for DSM-III-R, Nonpatient edition. Washington, DC, American Psychiatric Association

Szekely AM, Barbaccia ML, Costa E (1987): Effect of a protracted antidepressant treatment on signal transduction and $\left[{ }^{3} \mathrm{H}\right]-(-)$-baclofen binding at $\mathrm{GABA}_{\mathrm{B}}$ receptors. J Pharmacol Exp Ther 243:155-159

Thompson PA, Maes M, Meltzer HY (1994): Effects of the placebo control condition in neuroendocrine challenge studies. Psychiatr Res 52:317-326

Vance ML, Kaiser FL, Evans WS, Thorner MO, Furlanetto R, Rivier J, Vale W, Perisutti G, Frohman LA (1985): Evidence for a limited growth hormone (GH)-releasing hormone $(\mathrm{GHRH})$-releasable quantity of $\mathrm{GH}$ : Effects of 6-hour infusions of GHRH on GH secretion in normal man. J Clin Endocrinol Metab 60:370-375 